\title{
CULTURAL-SOCIOLOGICAL CHANGE OF PARADIGMS IN SOCIAL WORK
}

\author{
Hermína Mareková
}

\begin{abstract}
There is a lot of discussion about social work, its forms, and whether social work is needed. If so, then in its existing or a different form? Often, only subjective thoughts or practical experiences are presented. They are subjective because, by pointing out the unfavorable situation, they describe a certain unidentifiable barrier, a shortcoming in building this profession, which social work has not been able to overcome in the past long period. As if we were wasting our chances of change. The performance of social work still has a socialist flavor, and therefore the Western models adopted in our country since the end of 1980's have not met with legislative support. This situation was partly caused by the fact that we took over "a little of each corner", without complexity, as if the richer competencies remained somewhere at the border crossing between Kittsee and Bratislava. It is not possible to compare the beginnings of social care in our country, which began elsewhere in the world in the '30-'40s, because, for ideological reasons, there was a certain effort to discredit some issues, together with other deviant problems. These ideological motivations have already disappeared but were replaced by economic reasons, which continued to prevent social care from undergoing a change of opinion and structure. Evidence of these shortcomings is also the fact that no government has so far embarked on the creation of family social policy, as if this situation suited all actors. Within the EU, considerable financial support comes to the social area, but it disappears in the wallets of non-profit organizations, often without control, and that is why there is no such systematic change. Even very beneficial projects in various "non-profit" organizations work only until the allocated funds are spent, and after the expiration of the time required for the existence of the project by the EU, the project falls into oblivion, and those organizations often apply for a completely different project. Research data is missing for a systemic change. Without the available research data, we cannot even expect a change in paradigms, so we continue to lag behind the more developed part of the world in this area.
\end{abstract}

UDC Classification: 304, DOI: https://doi.org/10.12955/pss.v2.229

Keywords: social work, legislation, change

\section{Introduction}

Despite turbulent changes in society, building a functioning social system to help citizens is still faltering. Social work in our country cannot break free from the last century's point of view. It still wants to function paternalistically without the active participation of the dependent. Social work has remained on the periphery among the helping professions. This fact is most apparent when a social worker enters the territory of nursing professions while caring for a client, where competence clashes may occur, especially from insurance companies' position in paying for services. During its development, social work often overlapped into therapeutic disciplines any problems and views on such work. How much can we integrate social work health care into the context of social assistance? The still existing issue in the nursing system, whether a nurse is a practical nurse or a person who has graduated from secondary medical school, also contributes negatively to this situation. Thus, in the system at present, there are people with very different levels of education. Despite the level of education required by the EU, in a social services facility in a neighboring country, I experienced a nurse whose highest education was a Red Cross course, while the head nurse in the facility was a person with a secondary medical school, originally from Slovakia.

It is challenging to include social work into the nursing care system, when the nurse is a person who has completed 9 years of primary school, some years of secondary school, 5 years of university, or even some special qualifications. In practice, it looks like nurses who can perform medical procedures paid for by insurance companies have studied together for up to 18-20 years! They know little to be doctors, and they know too much to be good nurses. A social worker in health care should "fit in" somewhere in this system.

\section{Cultural-Sociological Change of Paradigms in Social Work}

There is a lot of discussion about social work, its forms, and whether social work is even needed in its existing form. Often, only subjective thoughts or practical experiences are presented. They are subjective, because, by pointing out the unfavorable situation, they describe a certain unidentifiable barrier, a shortcoming in the building of this profession, which social work has not been able to overcome in the past long period. As if we were wasting our chances of change. The performance of social work still has a socialist flavor, and so since the end of the 1980s, the Western models adopted in our country have not met with legislative support. This situation was partly caused by the fact that we

\footnotetext{
${ }^{1}$ Danubius University, Sládkovičovo, Slovakia, hermina.marekova@gmail.com
} 
took over "a little of each corner", without complexity, as if the richer competencies remained somewhere at the border crossing between Kittse and Bratislava.

As a result, complex systems that work elsewhere have been insufficiently effective in our country. This is partly because some key attributes are still missing in our country as if they have not crossed state borders. One of the serious shortcomings is the lack of research in the social field. Theoretical constructions without proper research and even practice in the social field do not bring the desired effect. At the beginning of the era of social work, we did not define the exact place of social work in our society.

Abroad, the systems cooperate with other parts of the state administration. For example, social work in the United States works closely with the police. According to the Bologna system, education has been taking place in our country since 2006, but a common (satisfactory) content of the study program has not yet been created. We know how social work is executed in our country, but we have less knowledge about its practical implementation in the West. There has even been a paradoxical situation when a university degree is not sufficient for certain social areas in our country, but the same activity can be carried out after several weeks of training in the form of courses with a final exam. The fact that for the performance of, e.g., supervision or mediation does not imply a university degree, but a professional certificate devalues the university studies and social work itself.

Social work is a specific area that should work in practice, upon social order, but only after relevant findings from relevant research. We have been doing this work for many decades without our knowledge of the need to do it.

As the name implies, social work is work done for the benefit of society, and it might seem to create new values. Although it does not create values, it tries to replace non-existent values. However, this is very problematic in the absence of value systems or the collision of disparate rules.

Occupations are, of course, practiced for earnings. However, as far as social work is concerned, the notion still exists that such a "helping" profession should be carried out in the form of charity, and every social worker or even doctor should work 24 hours a day and, if possible, free of charge, for the benefit of others. As if doing something like that for money was unethical. Social work often evokes the idea that it is not a job but rather a mission, motivated by the love of neighbor, and should be rewarded appropriately (i.e., lowly).

Social work has a number of contradictions and dilemmas arising not only from the name but also from its implementation. On the one hand, it is made to order by society through social policy. Even the subject of social work cannot be exactly crammed into the performance of one task because in this work, prevention is as important as the solution of individual cases. Social work is therefore trying to fill a certain shortcoming. This is often a justification for long-standing unresolved social issues, which may give the impression that "society cares." At the same time, we all know how much money is being poured into this area, but without a preliminary identification of needs and subsequent control and measurement of effectiveness, we are only creating new opportunities for sophisticated theft of a considerable amount of money.

Social work is a transdisciplinary science and profession whose ethical problems arise from specific work challenges. Some authors even understand social work as an applied ethic (Sárkány 2011). According to him, the goal of social work in specific situations is to fight for the recognition of human freedom, for human rights, duties, and social justice. Various definitions of social work have been created. Its international definition is as follows: Social work as a profession facilitates social change and development, social cohesion, and the empowerment and the liberation of people. The principles of social justice, human rights, collective responsibility, and respect for diversity are crucial to social work. It is based on theories of social work, social sciences, humanities, and local knowledge. Social work deals with people and structures for solving life problems and increasing well-being (IFSW, IASSW, 2013).

Who is a social worker? A social worker is an expert with a university degree who can be educated at all three levels of education. He or she should have extensive knowledge of the functioning of society and should be familiar with the social policy instruments through which he carries out his work.

The first question raises another one: What is social work? According to Pataki (2006), among the recipients of social services, a social worker monitors and helps. Opinions on social worker's education are very diverse, and there are opinions that a complete university education is unnecessary for the 
performance of social work. More precisely, that a diploma is unnecessary for "lunch delivery" or other care for the elderly.

There is a lack of social vision and long-term vision, so it happens that theorists defend (that is, we defend) what they teach without knowing the applicability of this theory in the daily practice of a social worker. Although there are professional organizations, the effort is very fragmented. Almost every major private social education institution has set up its own workplace, inviting others, often for a high fee. Despite efforts in this matter, the measurable result has not appeared. Social work is still done in the old ways. It would be necessary to define what we want to teach clearly, how, and to whom.

According to the Barclay Report (1982), a social worker needs two skills to work successfully. One of them is the knowledge of the social environment where the client is located, the way of the person's daily life, as well as the lives of people around him or her, the system and availability of organizations and institutions with which he or she comes into contact. Second, theoretical knowledge about the laws of human behavior is needed. The success of a social worker is precisely in how he or she can connect the different areas into successful cooperation for the benefit of the individual. The subject of social work is conflicts between different groups of society, which are influenced by the current socioeconomic situation and valid cultural and ethical norms in society. Not every methodology used in applied ethics is satisfactory.

The deductive model (top-down) cannot accurately describe the practice of social work, because the principle of human dignity and human rights cannot be mechanically applied to a given situation. It is difficult to decide which model is suitable for a given client.

The inductive method (bottom-up) is always based on a specific situation and tries to create ethical principles from it, which does not describe exactly the practice of social work, either.

The holistic model allows us to understand social work as an applied ethic because it explains a specific situation in the context of traditions based on everyday moral habits. However, it may collide with established societal stereotypes, which may conflict with current legislation and may even violate human rights.

According to Knoepffler (2010), the application of ethics is an adaptation to those rules of the game that are applied in practice and have their origins in tradition. This model provides a new, innovative explanation of the principles of human dignity and human rights. According to Sárkány (2011), this is why the term hermeneutic should be used instead of holistic, which would better reflect the peculiarities of the ethics of social work.

In carrying out social work, our values acquired during socialization and ethics adopted in everyday life become key because we must constantly decide what is right and fair (ethics), what is good and expected (values), and all this must be in line with applicable legislation.

Ethical principles cannot be unified due to differences in professional knowledge, and the performance of the profession is influenced, even if we are not aware of it, by different personal values and possible prejudices of the worker.

Social workers constantly find themselves in unclear situations during their profession's exercise, yet they have to make decisions. "It is somewhere here that an ethical dilemma is born, framed by the principle of abstract humanism: Should society support a non-integrated human being and identify abnormalities, or should it give priority to the disabled or people with Down syndrome, for example, for whom an easier inclusion in everyday activities is more probable?" (Kusín et al., 2019, p. 25.)

This is an ethical dilemma because they must respect the law and at the same time use a method of work that will allow the client to solve his or her difficult situation. It does not have to have a single satisfactory solution. When making decisions, it is important to have a deeper knowledge of ethical principles and possibilities in order to make an optimal decision. We often find ourselves in situations where we do not have enough information about the causes or possible outcomes. Ethical dilemmas occur mostly in human services.

A dilemma is such a necessity of choice when we do not have enough information or what we have is contradictory. Theoretically, these dilemmas have long been defined by various postulates; we just need to be more aware of the importance of solving these problems in practice, all the more so that these dilemmas arise in everyday practice, mainly in communication, and should be addressed precisely there. 
Communication and ethics are key attributes in the implementation of social work. In social work, ethical dilemmas arise in accepting a certain hierarchy or priorities of individual norms, while the adopted and applied values and norms can be counterproductive. This situation can cause a certain dilemma of the relationship between professional ethics and valid social norms. Social workers often have to make choices, even when they do not have enough information or the information comes from various sources (e.g., the media), is contradictory and does not create trust, without which cooperation is difficult or even impossible. Dilemmas appear on a professional level (missing competencies), on a personal level (patterns, models), as well as in the social and cultural area (customs, values, stereotypes), but they can also arise in the political field.

According to Banks (2000), there is a difference between ethical issues and dilemmas. According to her, the ethical dilemma arises when we have to choose between equally disadvantageous, contradictory, and it is not clear which alternative will be more correct. Our moral principles will ensure that anxiety and remorse remain in us, regardless of our choice. According to her, we must constantly re-evaluate professional ethics.

An ethical dilemma also arises when a social worker encounters one or more conflicting values. Right at the beginning is the dilemma between intervention and non-intervention. What takes precedence? Justice or equality? However, justice and equality do not always have to be in irreconcilable tension. Equality is an inherent component of the principle of justice. What may be in tension here is freedom and equality. The problem is in the proportion in which they are mixed. Efficiency or competence, or the right to free choice? Is it good what society expects, or what we have learned during socialization? There is also very strong and complex pressure from society. Every single intervention has a broader perspective, as in the case of an alcoholic: the whole family needs help, and the elements are both objective and subjective. The loyalty of a social worker often finds itself in the middle of a conflict of interest of the social worker and the client (the client has a different idea of solving his situation), of clients and institutions, but also in conflict with his or her own beliefs acquired during upbringing (socialization).

Objectivity is necessary so that a social worker is not just a dilettante, as Max Weber (1970) writes. Dilettantes differs from professionals only in that they are unsure of fixed working methods and are therefore largely unable to control, evaluate or realize the relevance of their ideas.

These tensions, dilemmas arise in various fields, such as professional, personal, social, political, cultural, and others. According to some sociologists, such as Bauman (2000), we can talk about "liquid modernity", because there is a strengthened individualization. According to Giddens (1994, p. 5), increasing reflexivity results in a decrease in respect for traditions and an increase in the importance of communication. According to him, the weaker the tradition, the more a person is forced to make personal choices in his or her life, for various reasons (possible ethical dilemmas). There is also a great deal of discussion about common values - whether common values are receding or social solidarity is declining (Putnam, 2000).

Our established, valid standards and value orientations are expected by society, and our work should be in accordance with the valid legislation, even if they are contradictory. In general, according to the ethical principle, all people are equal (see Universal Declaration of Human Rights and Constitution of the Slovak Republic). According to professional ethics, all people are equal in rights and responsibilities, and the priority is to take an interest in a person. But what should take precedence? From the position of the profession, social workers have a duty to help, if necessary, but they cannot interfere with a person's private life. They have to comply with legislation and prevent discrimination, but this will be very difficult without trust, without social solidarity.

In the practice of social work, priorities in various societies undergo constant changes in connection with cultural, socio-economic changes in history. The performance of social work is a long process with a person, completely different from the direction of a results-oriented society (as immediate as possible). Other dilemmas may include the question of employee motivation in a society where this work is greatly underestimated, both financially and socially.

Recognizing and solving dilemmas is very challenging. Adhering to ethical principles (such as accepting the value and dignity of each person, striving for social good, satisfying the institution and the client, constantly upgrading qualification) creates constant stress, and meeting this challenge is very 
demanding. Being constantly tolerant, acting flexibly, and being professionally prepared creates constant tension. It is important to recognize what ethical issues and dilemmas are involved - whether professional, personal (socialization), social, cultural, political, etc. - to find the optimal solution. In most of our social service facilities, social workers do not receive adequate professional assistance. They are mostly overloaded, among other reasons, by many clients, non-functional, lengthy procedures, and the lack of funds for supervision. Burnout syndrome is very common among them. Our prejudices about people or groups can be positive, but they are mostly negative, and our work can be discriminatory for certain groups of people. Supercision backed by legislation was supposed to solve all emerging problems.

Well-executed supervision could be an effective method for personality development, the aim of which is, among other things, the development of professional competencies. It is very important for society that social work be carried out by experts in the field so that the citizen solving his or her problem receives adequate help. (Mareková, 2019).

The biggest dilemma for a social worker is how to put into practice the learned skills that will be useful in a given case, while taking into account the client's values and adhering to ethical principles and legislation. There should be no discrimination in this work. Nevertheless, a social worker (even in the field) gets into dilemmas when working with a client for several reasons. He or she must respect the law because non-discriminatory social work can only be done based on respect for human rights and standards, social justice, and anti-discrimination, and must use the method of work that is most appropriate, most effective for the client (Mareková, 2013). This includes the socialization of the social worker, who does not have to agree inwardly and may have various prejudices. Not to mention the conflict of interests of the social worker with the client or the social worker with an institution. A public institution that is in charge of the operation of various social facilities very often expects loyalty from its employees, even at the expense of the interests of the clients for whom it was established.

\section{Conclusion}

The solution process is a very sensitive issue, and our accepted values may conflict with the expectations of the client, the company, and the institutions. The current social work is not prepared for this, and therefore the client is very often discriminated against. Recognizing ethical dilemmas in social work allows us to prevent the emergence of a negative situation before the emergence of ethical transgressions, and this applies both in social work and in everyday life. The basic principle should be acceptance of the value and dignity of each person, striving for social good, responsibility towards the client and the institution, professionalism, and education. It will certainly be necessary to re-establish the idea of the functioning of social work in our society, because a social worker may stand next to a client, become a supervisory body, gain a stronger status in society, and refuse to participate in this conflict. However, all this presupposes a strong status of social work in society, which it still lacks. Almost a quarter of a century has passed since the inception of social work, and the time has come, also under the influence of globalization, to rethink what goals and content will be most effective in its execution.

\section{References}

Banks, S. (2000). Ethics and Values in Social Works. Palgrave Mac Millan.

Barclay Report (1982). Social workers: Their role and tasks N.I.S.W. and Betford square. Press London

Bauman, Z. (2000). Liquid modernity. Cambridge, Polity Press. ISBN 0-7456-2410-.

Giddens, A. (1994). Living in a Post-Traditional Society. Giddens, A., Lash, S., 1994. Reflexive Modernization. Cambrige: Polity Press, $56-109$ p.

Knoepffler, N. (2010). Angewandte Ethik. Applied Ethics. Cologne. Weimar, Wien.

Kusín,V., Mareková, H., Šebestová, P. (2019). Zápas o l’udskú dôstojnost’ osôb so zdravotným postihnutím. 2019. The Struggle for Human Dignity of the People with Disabilities. Brno.

Mareková, H. (2013). Glosár pojmov rodovej rovnosti, rovnosti príležitostí a rodovo citlivej sociálnej práce pre sociálnych pracovnikov. Glossary of Gender Equality, Equal Opportunities and Gender-Sensitive Social Work for Social Workers. Trnava: Vydavatel'stvo Oliva.

Mareková, H. (2019). Premeny rodiny v čase. Kultúrno - historické paralely. Family Transformations in Time. Culturalhistorical Parallels. Brno: Vydavatel'stvo MSD.

Pataki, E. (2006). Kettös mandátum: a kontroll és segitö funkció problematikája a szociális képzésekben. Dual mandate: The issues of Monitoring and Support Functions in Social Education. In: Albert József szerk. Esélyek a szociális képzések 
megújulására. Possibilities of Reform in Social Education. Veszprém-Budapest: Veszprémi Érseki Hittudományi Föiskola Iskolaszövetség. 99-110.

Putnam, R. (2000). Bowling Alone. New York: Simon and Schuster

Sárkány, P. (2011). A szociális munka mint alkalmazott etika. Social work as Applied Ethics. Szociális szemle 1-2. Social person 1-2. P. 7-18.

Weber, M. (1970). Állam, politika, tudomány. State, Politics and Science. Budapest: Közgazdasági és Jogi Könyvkiadó. 